\title{
The Effect Of Debt Choice On Firm Value
}

\author{
Soonwook Hong, Yeungjin College, South Korea
}

\begin{abstract}
This study aims to verify the effects of different methods of debt financing on firm value. The most common methods used by firms to finance its operations are directly issuing corporate bonds in the capital market and borrowing through financial institutions such as banks. From the accounting perspective, there is no difference between corporate bonds and bank loans. However, from the economic perspective, corporate bonds and bank loans are different in terms of their characteristics. This study conducts with the assumption that the attributes of the type of debt selected determine its impact on firm value. The results indicate that firms that use corporate bonds more frequently than bank loans have a higher value.
\end{abstract}

Keywords: Bank Loan; Corporate Bond; Private Debt; Public Debt; Firm Value; MTB; Tobin’s Q

\section{INTRODUCTION}

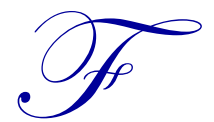

irm value is determined by numerous complex factors. Since Ball \& Brown (1968), numerous researchers have conducted studies on the capital market. Most of these studies focus on comparing the value relevance of accounting figures with share prices. The evaluation of firm value becomes an issue when deciding which information has value relevance. Ohlson (1995) investigated firm value using the information of book value of net assets and net earnings from the numerous accounting figures of a firm. However, subsequent researchers have argued that considering other information that reflects a firm's characteristics could not only explain the firm value better, but also intensify the usefulness of Ohlson (1995)'s model (Kwon et al. 2010; Kim, 2005).

Capital structure is the representative accounting figure that influences firm value. Since Modigliani \& Miller (1958), a lot of studies related to capital structure have been conducted in the fields of accounting as well as finance. Traditional theories on the determinants of capital structure, such as pecking order theory, trade-off theory, and market timing theory have focused on equity capital and debt capital. However, this study is conducted with the assumption that firm value could differ based on the selected method of financing that is, issuing corporate bonds or borrowing from financial institutions. Prior literatures have verified the various effects that arise from the type of debt being selected. Most of prior studies have focused on verifying the differences in firms' earnings management and conservatism depending on the choice of debt.

Information asymmetry exists between firms and investors. The information asymmetry between corporate bond investors and firms is larger than that between banks and firms. Information intermediaries such as credit rating agencies exist in order to reduce this asymmetry between corporate bond investors and firms. The accounting characteristics of corporate bonds and bank loans, which could be found in financial statements, are identical, but their characteristics are different from the standpoint of economics. As such, this study attempts to verify how the different characteristics influence the firm value.

\section{HYPOTHESES DEVELOPMENT}

According to Bhattacharya \& Chiesa (1995), private debt investors have greater access to a firm's internal information than public debt investors, as they are provided with its credit condition and investment plans during loan appraisal. Bharath et al. (2008) argued that private debt investors have higher monitoring efficiency than public debt investors. According to them, the agency problem could easily arise when firms issue public debts, but the possibility of bearing agency costs due to information asymmetry is relatively lower when firms issue private debts. Berlin \& Loeys (1988), Blackwell \& Kidwell (1988) argued that the information cost of corporate bonds is higher than that of bank loans. 
Kim \& Bae (2006) investigated the relationship between firm's characteristics, such as debt ratio and loan ratio, and conservatism. The results indicate that the inclination towards conservatism becomes stronger as the debt ratio increases and the loan ratio decreases. Haw et al. (2014) argued the effect of public debt on conservatism is stronger than that of private debt. On the other hand, Hong (2016b) directly compared and analyzed the relationship between corporate bond balance and loan balance from financial statements and the results suggested that firms with larger loan balance than corporate bond balance conduct conservative accounting operations.

Chun et al. (2011) compared the absolute value of discretionary accruals of firms that have a high private debt ratio with those that have a high public debt ratio. They argued that the former conduct more earnings management than the latter. Financial institutions, the creditors of private debts, can easily obtain information about a firm, the debtor, monitor its business, and take control by modifying terms and conditions of the contract, thereby reducing any uncertainty. Hence, private debt investors would incur a relatively lower agency cost that arises from information asymmetry. On the other hand, public debt investors cannot easily obtain information about firms, monitor its business, and alter the terms and conditions of the contract. Therefore, they would incur a higher agency cost that arises from information asymmetry. Information intermediaries such as credit rating agencies aim to resolve the problem of information asymmetry faced by public debt investors. Credit rating agencies usually calculate the firm's credit rating based on its financial information. (Black, 1975; Yoon \& Park, 1999)

However, Hong (2016c) concluded that firms that usually use corporate bonds conduct more upward earnings management than firms that usually uses loans. Kim (2010) investigated the value relevance between debt characteristics and book value of net assets and net earnings. Park (2013) stated that the characteristics of debt influence audit fees and Jung \& Lee (2014) argued that the characteristics of debt influence the firm's future earnings response coefficient. Hong (2016a) reported in detail the presence of differences in terms of earnings management, conservatism, and business performance evaluation between firms that issue corporate bonds through open competitive bidding and firms that do not.

The preceding literatures indicate that firms' accounting and financial characteristics differ depending on types of debt being used. Even though the results differ among researchers, it is clear that types of debt being selected have a differential impact on firms. This study establishes and verifies this hypothesis.

Hypothesis: When debt financing, firm value will differ depending on whether corporate bonds or loans are mainly used.

\section{THE MODEL}

The samples used in this study include firms that close their books in December and are listed on the Korea Exchange (KOSPI) from 1990 to 2015. Financial firms, which have different accounting standards, are excluded from the analysis. The data is collected from the databases provided by the TS-2000 of Korea Listed Companies Association and the DataGuide of FnGuide. The extreme values, the upper and lower 1\%, are adjusted through winsorization and the total samples used in the final analysis comprise 9,209 firm · year.

In order to analyze the effect of debt choice on firm value, the model of this study is established through equation (1) below. The market-to-book ratio (MTB) and Tobin's $Q$, which are usually used as proxies for firm value, are chosen as the dependent variables and $L O A N$, which refers to firms that use more loans than corporate bonds, is chosen as the main variable. The variables that are known to influence firm value are chosen as the control variables. SIZE is included to control firm size effect, $L E V$ is included to control financial soundness, $O C F$ and $R O A$ are included to control profitability, BETA is included to control risk, and $G W$ is included to control growth opportunities.

For robust analysis, the following three types of variables are used in the analysis: $L O A N_{-} D$, the dummy variable that equals 1 if loans are larger than corporate bonds and 0 otherwise; $L O A N_{-} G$, the continuous variable that indicates the value obtained by subtracting corporate bonds from loans; and $L O A N_{-} R$, the loan ratio.

$$
\begin{aligned}
& M T B_{t}\left(\text { or Tobin's } Q_{t}\right)=\beta_{0}+\beta_{1} L O A N_{-} D_{t}\left(\text { or } L O A N \_G_{t} \text { or } L O A N_{-} R_{t}\right)+\beta_{2} S_{Z} I Z E_{t}+\beta_{3} L E V_{t}+ \\
& \beta_{4} O C F_{t}+\beta_{5} B E T A_{t}+\beta_{6} G W_{t}+\beta_{7} R O A_{t}+\Sigma Y D+\Sigma I N D+\varepsilon_{t}
\end{aligned}
$$


$M T B=\quad$ market to book ratio $=$ market value of equity $/$ book value of equity

Tobin's $Q=$ (market value of equity + book value of debt) / book value of total asset

$L O A N_{-} D=\quad 1$ if loan is bigger than bond, otherwise 0

$L O A N \_G=$ loan - bond, scaled by beginning total asset

$L O A N \_R=\quad$ loan / (loan + bond)

SIZE $=\quad$ the natural logarithm of the total asset

$L E V=\quad$ leverage $=$ total debt $/$ total asset

$O C F=\quad$ cash flows from operating scaled by beginning total asset

$B E T A=\quad 3$ year systematic risk measured by market model

$G W=\quad$ sales growth rate

$R O A=\quad$ net income scaled by beginning total asset

$Y D=\quad$ year dummy variables

$I N D=\quad$ industry dummy variables

$\varepsilon=\quad$ residuals

EMPIRICAL RESULTS

Table 1. Descriptive statistics

\begin{tabular}{l|c|c|c|c|c|c}
\hline \multicolumn{1}{c|}{ Variables } & $\mathbf{N}$ & Mean & Std. & Median & Min & Max \\
\hline MTB & 9,209 & 1.082 & 0.867 & 0.869 & 0.142 & 5.423 \\
\hline Tobin's $Q$ & 9,209 & 1.006 & 0.348 & 0.952 & 0.446 & 2.505 \\
\hline LOAN_D & 9,209 & 0.569 & 0.495 & 1.000 & 0.000 & 1.000 \\
\hline LOAN_G & 9,209 & -0.004 & 0.120 & 0.005 & -0.340 & 0.382 \\
\hline LOAN_R & 9,209 & 0.603 & 0.386 & 0.625 & 0.000 & 1.000 \\
\hline SIZE & 9,209 & 26.457 & 1.532 & 26.194 & 23.710 & 30.838 \\
\hline LEV & 9,209 & 0.545 & 0.184 & 0.554 & 0.125 & 0.935 \\
\hline OCF & 9,209 & 0.050 & 0.084 & 0.048 & -0.198 & 0.298 \\
\hline BETA & 9,209 & 0.892 & 0.476 & 0.865 & -0.214 & 2.272 \\
\hline$G W$ & 9,209 & 0.078 & 0.200 & 0.056 & -0.544 & 0.930 \\
\hline ROA & 9,209 & 0.025 & 0.066 & 0.024 & -0.250 & 0.205 \\
\hline
\end{tabular}

(1) Refer to ‘THE MODEL (1)' for the definition of variables.

Table 1 illustrates the descriptive statistics of the total samples. The average of the MTB and Tobin's $Q$, the proxies for firm value, is slightly higher than 1. The average of $L O A N \_D$ is higher than 0.5 , which indicates that firms use more loans than corporate bonds. Meanwhile, the values of other control variables are not significantly different from the values derived in the preceding literatures.

Table 2. Pearson correlation matrix

\begin{tabular}{|c|c|c|c|c|c|c|c|c|c|c|c|}
\hline Variables & $M T B$ & Tobin's $Q$ & $L O A N \_D$ & LOAN_G & $L O A N \_R$ & SIZE & $L E V$ & $O C F$ & BETA & $G \boldsymbol{W}$ & $R O A$ \\
\hline MTB & 1.000 & & & & & & & & & & \\
\hline Tobin's $Q$ & $0.899^{* * *}$ & 1.000 & & & & & & & & & \\
\hline$L O A N \_D$ & $-0.073^{* * *}$ & $-0.100^{* * *}$ & 1.000 & & & & & & & & \\
\hline LOAN_G & $-0.053^{* * *}$ & $-0.077^{* * *}$ & $0.728^{* * *}$ & 1.000 & & & & & & & \\
\hline$L O A N \_R$ & $-0.088^{* * *}$ & $-0.115^{* * *}$ & $0.912^{* * *}$ & $0.744^{* * *}$ & 1.000 & & & & & & \\
\hline SIZE & 0.012 & $0.051^{* * *}$ & $-0.265^{* * *}$ & $-0.180^{* * *}$ & $-0.292^{* * *}$ & 1.000 & & & & & \\
\hline LEV & $0.154^{* * *}$ & $0.113^{* * *}$ & $-0.194^{* * *}$ & $-0.038^{* * *}$ & $-0.221^{* * *}$ & $0.049^{* * *}$ & 1.000 & & & & \\
\hline$O C F$ & $0.049^{* * *}$ & $0.087^{* * *}$ & $0.078^{* * *}$ & $0.071^{* * *}$ & $0.085^{* * *}$ & $0.103^{* * *}$ & $-0.190^{* * *}$ & 1.000 & & & \\
\hline BETA & $0.030^{* * *}$ & $0.039^{* * *}$ & $-0.047^{* * *}$ & -0.003 & $-0.051^{* * *}$ & $0.223^{* * *}$ & $0.089^{* * *}$ & $-0.067^{* * *}$ & 1.000 & & \\
\hline$G W$ & $0.129^{* * *}$ & $0.144^{* * *}$ & 0.001 & -0.014 & 0.005 & -0.013 & $0.100^{* * *}$ & $0.113^{* * *}$ & $-0.027^{* *}$ & 1.000 & \\
\hline$R O A$ & $0.088^{* * *}$ & $0.127^{* * *}$ & $0.046^{* * *}$ & -0.010 & $0.062^{* * *}$ & $0.091^{* * *}$ & $-0.379^{* * *}$ & $0.432^{* * *}$ & $-0.097^{* *}$ & $0.259^{* * *}$ & 1.000 \\
\hline
\end{tabular}

(1) Refer to 'THE MODEL (1)' for the definition of variables.

(2) ${ }^{* * * * *}$, and $^{*}$ significant at the $1 \%, 5 \%$, and $10 \%$ levels, respectively. 
Table 2 illustrates the correlations among the variables. As expected, the $M T B$ has a very strong positive correlation with Tobin's $Q$ and $L O A N_{-} D, L O A N_{-} G$, and $L O A N_{-} R$ have strong positive correlations among themselves. It also illustrates that firm value has a negative correlation with the three $L O A N$ variables.

Table 3. Univariate analysis

\begin{tabular}{|c|c|c|c|c|}
\hline Variables & $L O A N \_D=1$ & $L O A N \_D=0$ & Difference & t-value \\
\hline MTB & 1.027 & 1.155 & 0.128 & $6.98^{* * *}$ \\
\hline Tobin's $Q$ & 0.976 & 1.046 & 0.070 & $9.67^{* * *}$ \\
\hline
\end{tabular}

(1) Refer to 'THE MODEL (1)' for the definition of variables.

(2) ${ }^{* * * * *}$, and $^{*}$ significant at the $1 \%, 5 \%$, and $10 \%$ levels, respectively.

Table 3 illustrates the results of the univariate analysis that compares the value of firms that use more loans with firms that use more corporate bonds. The results from both proxies of firm value indicate that firms that use more corporate bonds have a higher value.

Panel A and Panel D in Table 4 show that the regression analysis using the dummy variable $L O A N_{-} D$ as the main variable supports the hypothesis. The regression analysis that uses the MTB and Tobin's $Q$ as the dependent variable indicates a significant negative value for every the $L O A N_{-} D$ coefficient. It indicates that firms that use more corporate bonds than loans have a higher value. Coefficients of control variables are not materially different from previous studies.

Panel B and Panel E in Table 4 show that the regression analysis using the continuous variable $L O A N \_G$ as the main variable supports the hypothesis. The regression analysis that uses the MTB and Tobin's $Q$ as the dependent variable indicates a significant negative value for every the $L O A N_{-} G$ coefficient. It indicates that firms that use more corporate bonds than loans have a higher value.

Panel $\mathrm{C}$ and Panel $\mathrm{F}$ in Table 4 show that the regression analysis using the ratio variable $L O A N \_R$ as the main variable supports the hypothesis. The regression analysis that uses the MTB and Tobin's $Q$ as the dependent variable indicates a significant negative value for every the $L O A N_{-} R$ coefficient. It indicates that firms that use more corporate bonds than loans have a higher value.

Additionally, in every analysis, F-value is significant and variance inflation factor is low enough to avoid multicollinearity problems. 
Table 4. Regression analysis

\begin{tabular}{|c|c|c|c|c|c|c|}
\hline \multirow[b]{3}{*}{ Variables } & \multicolumn{6}{|c|}{ Firm Value $=$ MTB } \\
\hline & \multicolumn{2}{|c|}{$\begin{array}{c}\text { Panel A } \\
L O A N=L O A N \_D\end{array}$} & \multicolumn{2}{|c|}{$\begin{array}{c}\text { Panel B } \\
L O A N=L O A N_{-} G\end{array}$} & \multicolumn{2}{|c|}{$\begin{array}{c}\text { Panel C } \\
L O A N=L O A N_{-} R\end{array}$} \\
\hline & Coeff. & t value & Coeff. & t value & Coeff. & t value \\
\hline Intercept & 1.958 & $10.71^{* * *}$ & 1.781 & $10.22^{* * *}$ & 2.130 & $11.42^{* * *}$ \\
\hline$L O A N$ & -0.089 & $-4.94^{* * * *}$ & -0.293 & $-4.12^{* * * *}$ & -0.154 & $-6.54^{* * * *}$ \\
\hline SIZE & -0.037 & $-5.66^{* * *}$ & -0.033 & $-5.17^{* * *}$ & -0.041 & $-6.29^{* * *}$ \\
\hline$L E V$ & 1.136 & $19.64^{* * *}$ & 1.167 & $20.20^{* * *}$ & 1.122 & $19.38^{* * *}$ \\
\hline$O C F$ & 0.437 & $3.94^{* * *}$ & 0.432 & $3.89^{* * *}$ & 0.453 & $4.09^{* * *}$ \\
\hline BETA & 0.059 & $3.12^{* * *}$ & 0.061 & $3.20^{* * *}$ & 0.060 & $3.16^{* * *}$ \\
\hline$G W$ & 0.239 & $5.36^{* * *}$ & 0.232 & $5.20^{* * *}$ & 0.242 & $5.44^{* * *}$ \\
\hline$R O A$ & 2.072 & $13.24^{* * *}$ & 2.068 & $13.21^{* * *}$ & 2.085 & $13.33^{* * *}$ \\
\hline$Y D$ & \multicolumn{2}{|c|}{ Included } & \multicolumn{2}{|c|}{ Included } & \multicolumn{2}{|c|}{ Included } \\
\hline$I N D$ & \multicolumn{2}{|c|}{ Included } & \multicolumn{2}{|c|}{ Included } & \multicolumn{2}{|c|}{ Included } \\
\hline F value & \multicolumn{2}{|c|}{50.42} & \multicolumn{2}{|c|}{50.22} & \multicolumn{2}{|c|}{50.90} \\
\hline Adj. $\mathrm{R}^{2}$ & \multicolumn{2}{|c|}{0.205} & \multicolumn{2}{|c|}{0.204} & \multicolumn{2}{|c|}{0.206} \\
\hline $\mathrm{N}$ & \multicolumn{2}{|c|}{9,209} & \multicolumn{2}{|c|}{9,209} & \multicolumn{2}{|c|}{9,209} \\
\hline
\end{tabular}

\begin{tabular}{|c|c|c|c|c|c|c|}
\hline \multirow[b]{3}{*}{ Variables } & \multicolumn{6}{|c|}{ - } \\
\hline & \multicolumn{2}{|c|}{$\begin{array}{c}\text { Panel D } \\
L O A N=L O A N \_D\end{array}$} & \multicolumn{2}{|c|}{$\begin{array}{c}\text { Panel E } \\
L O A N=L O A N_{-} G\end{array}$} & \multicolumn{2}{|c|}{$\begin{array}{c}\text { Panel F } \\
L O A N=L O A N \_R\end{array}$} \\
\hline & Coeff. & t value & Coeff. & t value & Coeff. & t value \\
\hline Intercept & 1.248 & $17.32^{* * *}$ & 1.128 & $16.41^{* * *}$ & 1.331 & $18.11^{* * *}$ \\
\hline LOAN & -0.057 & $-7.98^{* * *}$ & -0.173 & $-6.16^{* * *}$ & -0.090 & $-9.70^{* * *}$ \\
\hline$S I Z E$ & -0.008 & $-2.99^{* * *}$ & -0.005 & $-1.96^{* *}$ & -0.010 & $-3.78^{* * *}$ \\
\hline$L E V$ & 0.366 & $16.06^{* * *}$ & 0.386 & $16.91^{* * *}$ & 0.359 & $15.74^{* * *}$ \\
\hline$O C F$ & 0.269 & $6.15^{* * *}$ & 0.263 & $6.01^{* * *}$ & 0.276 & $6.31^{* * *}$ \\
\hline BETA & 0.023 & $3.08^{* * *}$ & 0.024 & $3.20^{* * *}$ & 0.024 & $3.15^{* * *}$ \\
\hline$G W$ & 0.128 & $7.29^{* * *}$ & 0.124 & $7.03^{* * *}$ & 0.130 & $7.40^{* * *}$ \\
\hline$R O A$ & 0.881 & $14.27^{* * *}$ & 0.878 & $14.21^{* * *}$ & 0.888 & $14.41^{* * *}$ \\
\hline$Y D$ & \multicolumn{2}{|c|}{ Included } & \multicolumn{2}{|c|}{ Included } & \multicolumn{2}{|c|}{ Included } \\
\hline$I N D$ & \multicolumn{2}{|c|}{ Included } & \multicolumn{2}{|c|}{ Included } & \multicolumn{2}{|c|}{ Included } \\
\hline F value & \multicolumn{2}{|c|}{59.54} & \multicolumn{2}{|c|}{58.84} & \multicolumn{2}{|c|}{60.36} \\
\hline Adj. $\mathrm{R}^{2}$ & \multicolumn{2}{|c|}{0.238} & \multicolumn{2}{|c|}{0.232} & \multicolumn{2}{|c|}{0.236} \\
\hline $\mathrm{N}$ & \multicolumn{2}{|c|}{9,209} & \multicolumn{2}{|c|}{9,209} & \multicolumn{2}{|c|}{9,209} \\
\hline
\end{tabular}

(1) Refer to 'THE MODEL (1)' for the definition of variables.

(2) ${ }^{* * * * *}$, and ${ }^{*}$ significant at the $1 \%, 5 \%$, and $10 \%$ levels, respectively.

\section{CONCLUSION}

This study conducted the analysis with the assumption that firm value can differ depending on the types of debt being selected. It went one step further from the debt ratio, which is the representative accounting figure and verified that the debt choice can influence firm value. The correlation, univariate, and regression analyses all indicated identical results, thus verifying that the value of firms that use more corporate bonds than loans is higher. This implies that the capital market's evaluation is more favorable towards firms that use more corporate bonds than loans. Firm value as well as earnings management, conservatism, audit fee and future earnings response coefficient differ depending on the debt choice.

The research conducted by Hong (2016b), who used a similar research design and samples to this study, posited that firms that use more corporate bonds conduct more upward earnings management and less conservative accounting operation as compared to firms that use more loans. The purpose of firms that conduct upward earnings management and non-conservative accounting operation is to obtain better evaluation in the capital market. If capital market 
participants realize that firms have conducted upward earnings management and non-conservative accounting operation, firm value will be negatively impacted. However, considering this study's empirical results, which indicate that firm value that use more corporate bonds is higher than that of firms that use more loans, implies that the capital market participants are not aware of upward earnings management and non-conservative accounting operations conducted by firms.

This study is significant because it verifies that the type of debt selected is among the various factors that influence firm value. Therefore, firms should practice caution in selecting the type of debt. Moreover, investors and financial analysts should include the characteristics of debt used for financing firms as a subject of analysis.

\section{AUTHOR BIOGRAPHY}

Soonwook Hong is an Assistant Professor, School of Business, Yeungjin College, Daegu, South Korea. E-mail: soonwookhong@yahoo.com

\section{REFERENCES}

Ball, R., and P. Brown. 1968. An empirical evaluation of accounting income numbers. Journal of Accounting and Research 6(2): $159-178$.

Berlin, M., and J. Loeys. 1988. Bond covenants and delegated monitoring. Journal of Finance 43(2): 397-412.

Bharath, S. T., J. Sunder, and S. V. Sunder. 2008. Accounting quality and debt contracting. Accounting Review 83(1): 1-28.

Bhattacharya, S., and G. Chiesa. 1995. Proprietary information, financial intermediation, and research incentives. Journal of Financial Intermediation 4(4): 328-357.

Black, F. 1975. Bank funds management in an efficient market. Journal of Financial Economics 15: 323-339.

Blackwell, D. W., and D. S. Kidwell. 1988. An investigation of cost differences between public sales and private placement of debt. Journal of Financial Economics 22(2): 253-278.

Chun, S. B., H. J. Kwon, and S. H. Kim. 2011. Debt financing and earnings management. Korean Study of Accounting, Tax, and Audit 53(2): 39-78.

Haw, I. M., J. J. Lee, and W. J. Lee. 2014. Debt financing and accounting conservatism in private firms. Contemporary Accounting Research 31(4): 1220-1259.

Hong, S. W. 2016a. Accounting characteristics of corporations by bonds issuing methods: Focused on public corporations in South Korea. Journal of Applied Business Research 32(4): 1217-1222.

Hong, S. W. 2016b. Debt characteristics and conservatism. Korean Study of Accounting, Tax, and Audit 58(3): 1-39.

Hong, S. W. 2016c. Earnings management by debt financing types. International Business Management.

Jung, H. U., and K. I. Lee. 2014. Debt financing and future earnings response coefficient. Korean Study of Corporation Management 21(4): 41-61.

Kim, E. H. 2005. Value-relevance of nonfinancial information in the REITs. Korean Corporation Management Study 12(2): 111.

Kim, J. O. 2010. The effect of debt characteristics on value relevance. Korean Accounting Review 35(1): 63-93.

Kim, J. O., and G. S. Bae. 2006. The role of corporate characteristics to conservatism. Korean Accounting Review 31(1): 69-96.

Kwon, S., M. Kim, S. Shon, K. Choi, and B. Han. 2010. Usefulness of accounting information in capital market. ShinYoungSa, Seoul 464-488.

Modigliani, F., and M. Miller. 1958. The cost of capital, corporation finance, and the theory of investment. American Economic Review 48: 655-669.

Ohlson, J. A. 1995. Earning, book value, and dividends in equity valuation. Contemporary Accounting Research 11(2): 661-687.

Park, B. J. 2013. The study on the relation between debt characteristics and audit fee. Korean Study of Business Education 28(1): 183-209.

Yoon, S. H., and R. S. Park. 1999. Debt choice and equilibrium of capital market. Asian Review of Financial Research 12(2): 125-163. 